\title{
Castor bean: main uses and biodiversity in the Adamawa, Cameroon
}

\author{
Lucien TATCHUM TCHUENTEU*, Awal MOHAMAMED and Clautilde MEGUENI \\ Department of Biological Sciences, Faculty of Science, University of Ngaoundere-Cameroon, P.O. Box 454 \\ Ngaoundere, Cameroon. \\ *Corresponding author; E-mail: tatchumlucien@yahoo.fr; Tél: +237 699145141
}

\begin{abstract}
Ricinus communis L. (castor bean) is an oilseed plant with multiple socio-economic benefits. It grows wild in Cameroon. The study aimed at determining main uses, describing, evaluating the carbon stock as well as carbon credits and geolocalizing castor bean accessions from Adamawa Cameroon. The location of various sites for ethnobotanical survey was identified by random sampling techniques which consist in randomly selecting the various locations, overall sample consists of 1440 peoples; the respondents were questioned individually using a questionnaire form. Results showed that castor bean is used to treat several diseases; seeds oil is consumed and plants present margico-religious powers. Four local castor bean accessions (Vina, Martap, Nyambaka and Bélel) were identified. Overall, there was a significant difference $(\mathrm{p}<0.05)$ between castor bean accessions identified with respect to the physical characteristics of vegetative organs and seeds. Plants of Bélel accession were tallest $(302.96 \pm 44.36 \mathrm{~cm})$ while the smallest plants height $(148.63 \pm 19.05 \mathrm{~cm})$ were from Vina accession. Vina accession was the most widespread while Nyambaka and Bélel accessions were the least widespread in the study areas. This information will be useful in the implantation program of castor bean as alternative crop of the Cameroonian agriculture.
\end{abstract}

(C) 2020 International Formulae Group. All rights reserved.

Keywords: Ricinus communis L., ethnobotanical survey, vegetative organs, carbon stock, geolocalizing, Adamawa-Cameroon.

\section{INTRODUCTION}

Castor bean (Ricinus comminus L.) is an oilseed plant (40-60\% oil) cultivated for its seeds which yield viscous, pale and nonvolatile yellow oil (Pina et al., 2005). This oil has many industrial applications, notably in the manufacture of paints, dyes, inks, waxes, varnishes, lubricants and brake fluids (Ogunniyi, 2006). Castor oil obtained by cold pressing of seeds is also used in household for soap production and as purgatives and laxatives (Weiss, 2000). Castor bean is grown for its seeds rich in oil (Pina et al., 2005; Tchuenteu, 2014).

This plant with hight agroeconomic values has been extensively cultivated in India (870 ha), China (220 ha) and Brazil (163 ha) (Pina et al., 2005). World production of oil from castor bean seeds is estimated at about 550000 tons per year (Scholz and Da Silva, 2008). India alone exports $80 \%$ of castor oil and therefore largely dominates the market. Ethiopia, South Africa, Angola, Kenya and Tanzania are the main producing countries of castor bean in Africa (Diallo et al., 2013). 
Recent work on castor bean aimed at selecting the genotypes with greater seeds yield. This is how in a previous study, we did the agronomic characterization of 03 local accessions of castor bean from North Cameroon and revealed that castor bean productivity varies according to genotype and experimental area (Tchuenteu, 2014). In addition, Ezzedine (2017) studied the genetic variation and seed yield in Tunisian castor bean and revealed that seeds yield varied between populations. Despite these many works, castor bean grows wild in Cameroon. The characteristics of castor bean from countries such as India, China, U.S.A. and Madagascar have been studied (Tchuenteu et al., 2013).

To the best of our knowledge, no work has been conducted on inventory and characterization of castor bean accessions of Sudano-Guinean savannahs of Cameroon. This lack of data seems to be a handicap for appreciation of local castor bean accessions, which may not only be an additional source of income for Cameroonian peasant, but also present interesting properties in chemical industry. This oilseed plant with multiple socio-economic benefits is among the species under exploited and under valorized by Cameroonian populations. In this respect there is a risk of genetic erosion and loss of potentiality.

The objective of current work consisted to (1) identify the main uses of castor bean in order to determine local peasants knowledge of this plant and their perception of its socioeconomical value; (2) describe the physical characteristics of local castor bean accessions; (3) assess the carbon stock as well as carbon credits of local castor bean accessions; (4) geolocate castor bean accessions in the Sudano-Guinean savannahs of Adamawa Cameroon. Data obtained regarding the identification of castor bean accessions and geolocation should be used in the implantation program of castor bean as alternative crop for the Cameroonian agriculture.

\section{MATERIALS AND METHODS}

\section{Study area}

This work took place in 02 Divisions (Vina and Mbéré) of Adamawa Cameroon region. Vina Division has 08 Sub-division (Ngaoundere I, Ngaoundere II, Ngaoundere III, Bélel, Martap, Mbé, Nganha and Nyambaka) while Mbéré Division has 04 Subdivision (Meiganga, Djohong, Dir and Ngaoui). This area is located between the $6^{\text {th }}$ and $8^{\text {th }}$ degrees of north latitude and between the $10^{\text {th }}$ and $16^{\text {th }}$ degrees of east longitude. Climate of Adamawa Cameroon region is from the Sudano-Guinean type (Deffo et al., 2009). Vegetation is various and composed of grasslands; grassy, shrubby and tree savannahs (Mapongmetsem et al., 2000). Agriculture and livestock are the main activities (Deffo et al., 2010). Administratively, Adamawa Cameroon region has 05 Divisions (Vina, Mbéré, Faro and Deo, Djerem, Mayo Banyo).

\section{Ethnobotanical survey Survey design}

Ethnobotanical surveys were conducted among peasants and sellers of therapeutic products. The location of various sites for ethnobotanical survey was identified by random sampling techniques which consist in randomly selecting the various locations (Dagnelie, 2013). In this work, sample was divided into 24 strata at level of 2 villages per Sub-division, corresponding to the eight (08) Sub-divisions of Vina Division and four (04) Sub-divisions of Mbere Division. Samples of 60 peoples were formed for each of 24 strata and overall sample was 1440 participants.

\section{Data collection}

The ethnobotanical survey was conducted from March to July 2017 (05 months).To collect the ethnobotanical data, the respondents were questioned individually using a questionnaire form. The interview was standardized. Data collected during surveys relate to castor bean plants such as knowledge levels, uses and organs used. 


\section{Physical characterization of local castor bean accessions}

Physical characteristics of plants such as color of vegetative organs, plants height, petiole length and leaf area of castor bean plants were evaluated and 30 plants are sample. The leaf area was determined according to Lauri (1988) using following formula: $\mathrm{SL}=1.285 \times(\mathrm{L} 1 \times \mathrm{L} 2.3) 0.98$ where $\mathrm{SL}=$ blade area; $\mathrm{L} 1=$ length of main lobe and L2.3 = average length of both lobes adjacent to main lobe. The total dry biomass of plants was evaluated using the following formula: $\mathrm{DBP}=0.84 \mathrm{~T}-0.59$ where $\mathrm{DBP}=$ dry biomass of a plant and $\mathrm{T}=$ plant height as previously described Tchuenteu et al. (2013). For evaluation of seeds physical characteristics, length, width and thickness of seeds were assessed using a 0.01 precision electronic vernier caliper; seeds weight is evaluated using a 0.01 precision electronic scale and 100 seeds are sampled.

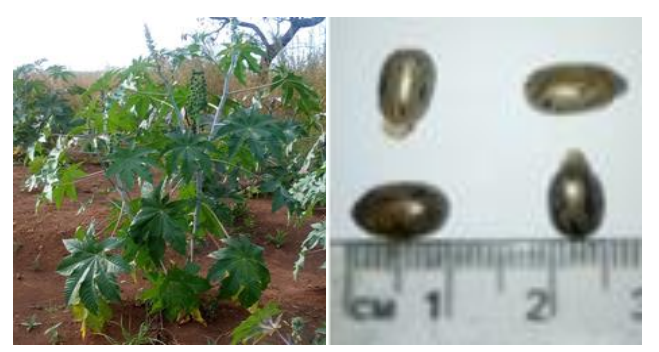

A : Vina accession

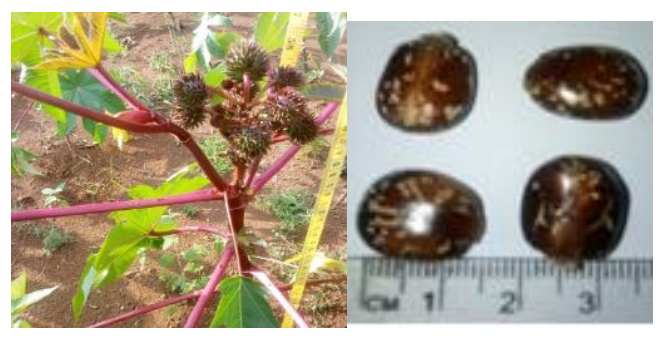

C : Nyambaka accession

\section{Geolocalization of castor bean accessions}

The geographical location of different castor beans from, Vina and Mbere Divisions was made using a GPS (Global Positioning System) brand Garmin ${ }^{\circledR}$. The geographic coordinates of castor bean accessions encountered in the study area were recorded. The QGIS 2.8 (Quantum Geographic Information System) software was used to realize a geographical map. Geographic coordinates were downloaded using GPSBabel, a program used to transfer GPS data from the GPS device to the computer. These coordinates were entered into a QGIS study area that pops up from the bottom of the map by loading a MapInfo layer using the internet connection.

\section{Statistical analysis}

Data were subjected to variance analysis followed by the Duncan multiple range tests when any significant effect was observed. The statistical software "Statgraphics plus" was used for this propose. Excel 2010 software was used for data entry and graphing.

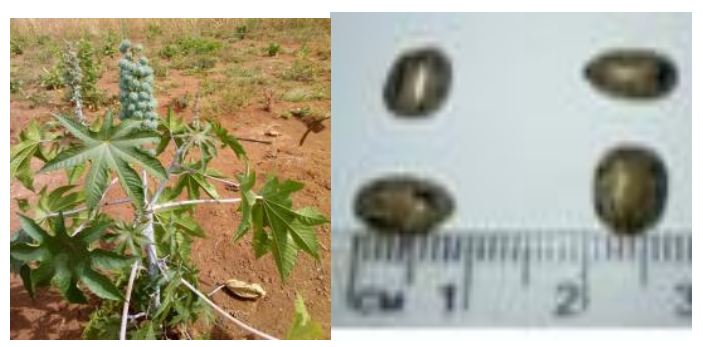

B : Martap accession

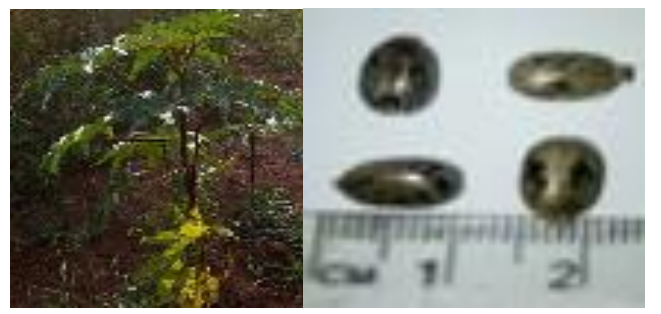

D : Bélel accession

Figure 1: Color of plants and seeds physical characteristics depending on castor bean accessions. 


\section{RESULTS}

\section{Ethnobotanical survey on Castor bean plant}

\section{Knowledge and use levels of castor bean according to vegetative organs}

Table 1 shows the knowledge and use levels of castor bean according to plants organs in Vina and Mbere Divisions of Adamawa Cameroon region. It comes from table 1 that almost half of the population (44\%) has no knowledge on castor bean. Concerning the utilities of castor bean, roots were the most used organs with a utilization rate of $37 \%$, followed by seeds (30\%), leaves (19\%) and stems (14\%).

\section{Uses of castor bean}

In Adamawa Cameroon, castor bean is used mainly as therapeutics $(69,43 \%)$, magicoreligious $(17,2 \%)$ and food $(13.37 \%)$. Castor bean is not cultivated in this area. Therapeutically, oil extracted from seeds is used for treatment of rheumatism by simple massage. The anointed oil on skin treats leprosy. Seeds ingestion heals intestinal worms, facilitates delivery by accelerating uterine contractions during delivery and prevents insomnia. Also, seeds are purgative and laxative. The oral absorption of roots decoction treats internal hemorrhage and arterial hypertension. The bath of a mouth by roots decoction treats toothache. The massage with the previously boiled castor bean leaves heals fracture and sprain. The leaf decoction is used against dysmenorrhea. Also, the leaves have anti-inflammatory properties. At a magico-religious level, castor oil is for delivering anybody from a spell by fumigates the patient using leaves and roots decoction mixed with several other products; stems and leaves are used for manufacture of magic counter-balls commonly called "yéssi" among Bororo. Seeds oil is used for cooking. The application of leaves at bottom of traditional fermentor accelerates the wines fermentation. Leaves and stems are burned to obtain native salt or potash much appreciated in Adamawa Cameroon kitchens.

\section{Physical characterization of plants Vegetative organs}

The vegetative apparatus of castor bean from the study area showed presents different colors. The vegetative organs of Vina and Martap accessions are green while those of Nyambaka and Bélel accessions are violet. As shown in table 2 , there is a significant difference ( $p$ <0.05) in plant height, limb area and petiole length between the 04 local castor bean accessions identified in the present work. Bélel accession showed the highest plants height $(302.96 \pm 44.36 \mathrm{~cm})$ while the smallest $(148.63 \pm 19.05 \mathrm{~cm})$ was recorded with the Vina accession. Meanwhile Martap and Nyambaka accessions presented intermediate values of plant height which were $297.13 \pm$ $91.50 \mathrm{~cm}$ and $201.10 \pm 32.09 \mathrm{~cm}$ respectively. Moreover, Limb area varied from $59.93 \pm$ $23.26 \mathrm{~cm}^{2}$ for Martap accession to $329.60 \pm$ $79.31 \mathrm{~cm}^{2}$ for Bélel accession. Limb areas of Vina and Nyambaka accessions exhibited intermediate values and are $271.13 \pm 43.3$ and $29.66 \pm 2.84 \mathrm{~cm}^{2}$ respectively. Petiole lengths of Vina, Nyambaka and Bélel accessions of castor bean were $29.90 \pm 2.48 ; 29.66 \pm 2.84$ and $28.23 \pm 1.33 \mathrm{~cm}$ respectively. In general, petiole length of Vina, Nyambaka and Bélel accessions was 3.74 fold higher than that of Martap accession.

\section{Seeds}

Seeds physical characteristics vary significantly $(\mathrm{p}<0.05)$ between the four castor accessions (Table 3). In general, seeds of Nyambaka accession have the greatest values of physical characteristics studied (length, width, thickness and weight). Seeds of Vina accession had the lowest values of these parameters while those of Martap and Bélel accessions presented intermediate values. Overall, weight, length, width and thickness of seeds of our local castor bean accessions were $0.16 \pm 0.05 \mathrm{~g} ; 0.95 \pm 0.06 \mathrm{~cm} ; 0.63 \pm$ $0.11 \mathrm{~cm}$ and $0.47 \pm 0.06 \mathrm{~cm}$ respectively.

\section{Dry biomass of castor bean plants, carbon stock and carbon credit}

The analysis of variance (ANOVA) showed that there was a significant difference $(p<0,05)$ between Vina, Martap, Nyambaka 
and Bélel accessions of castor bean obtained in this study with respect to dry biomass, carbon stock and carbon credit (Table 3). Bélel accession presented the highest values for these parameters while Vina accession showed the smallest values. Dry biomass of Bélel accession of castor bean was 3; 1.03 and 2.17 fold greater than those of Vina, Martap and Nyambaka respectively.

\section{Geolocation of castor bean from Vina and Mbéré Divisions of Adamawa Cameroon}

Figure 2 shows the geographical map of both Divisions of Adamawa Cameroon region, Vina and Mbéré with locations of Vina, Martap, Nyambaka and Bélel accessions of castor bean identified in this work. Vina, Martap and Belel accessions are present in the two Divisions that were the subject of this study. However, among 12 Sub-divisions of
Vina and Mbéré Divisions, Vina, Martap, Nyambaka and Bélel accessions of castor bean are found in 10;08; 02 and 03 Subdivision respectively. Vina accession does not exist in Mbé Sub-division of Vina Division and Dir Sub-division of Mbéré Division. Martap accession is not found in Martap and Mbé Sub-division of Vina division and in the both Sub-division, Dir and Ngaoui of Mbéré division. Nyambaka accession is found only in 02 Sub-division of Vina division: Ngaoundéré III and Nyambaka. Concerning Bélel accession, it is present in Belel and Martap Sub-division of Vina Division and in Meiganga Sub-division of Mbéré Division. These results obtained on geolocalisation of the local castor bean accessions suggest that Vina accession is the most widespread while the Nyambaka and Belel accessions are the least widespread in our study areas.

Table 1: Knowledge and use levels of castor bean depending on organs of plant.

\begin{tabular}{ccccccc}
\hline \multicolumn{2}{c}{$\begin{array}{c}\text { Rate of knowledge (\%) } \\
\text { Knowledge }\end{array}$} & \multicolumn{4}{c}{ Rate of use according to the parts of plant (\%) } \\
unknowing & Roots & stem & leaves & seeds \\
\hline 56 & 44 & 37 & 14 & 19 & 30 \\
\hline
\end{tabular}

Table 2: Physical characteristics of vegetative organs and seeds.

\begin{tabular}{|c|c|c|c|c|}
\hline \multirow[b]{2}{*}{ Parameters } & \multicolumn{4}{|c|}{ Accessions of castor bean } \\
\hline & $\mathbf{W}$ & $\mathbf{X}$ & $\mathbf{Y}$ & $\mathbf{Z}$ \\
\hline $\mathrm{PH}(\mathrm{cm})$ & $148.63 \pm 19.05^{\mathrm{a}}$ & $297.13 \pm 91.5^{\mathrm{c}}$ & $201.10 \pm 32.09^{b}$ & $302.96 \pm 44.36^{\mathrm{c}}$ \\
\hline $\mathrm{LA}\left(\mathrm{cm}^{2}\right)$ & $271.13 \pm 43.30^{c}$ & $59.93 \pm 23.26^{\mathrm{a}}$ & $206.66 \pm 55.56^{\mathrm{b}}$ & $329.60 \pm 79.31^{\mathrm{d}}$ \\
\hline PL (cm) & $28.23 \pm 1.33^{\mathrm{b}}$ & $7.83 \pm 2.00^{\mathrm{a}}$ & $29.66 \pm 2.84^{\mathrm{b}}$ & $29.90 \pm 2.48^{b}$ \\
\hline $\mathrm{SL}(\mathrm{cm})$ & $0.88 \pm 0.04^{\mathrm{a}}$ & $0.92 \pm 0.10^{\mathrm{b}}$ & $1.03 \pm 0.03^{\mathrm{c}}$ & $0.95 \pm 0.03^{\mathrm{b}}$ \\
\hline SWi (cm) & $0.54 \pm 0.03^{\mathrm{a}}$ & $0.59 \pm 0.09^{\mathrm{b}}$ & $0.79 \pm 0.03^{c}$ & $0.61 \pm 0.10^{\mathrm{b}}$ \\
\hline $\mathrm{ST}(\mathrm{cm})$ & $0.41 \pm 0.01^{\mathrm{a}}$ & $0.48 \pm 0.03^{\mathrm{b}}$ & $0.55 \pm 0.03^{\mathrm{c}}$ & $0.43 \pm 0.02^{\mathrm{a}}$ \\
\hline SWe (g) & $0.12 \pm 0.02^{\mathrm{a}}$ & $0.13 \pm 0.03^{\mathrm{a}}$ & $0.24 \pm 0.04^{\mathrm{c}}$ & $0.15 \pm 0.02^{\mathrm{b}}$ \\
\hline
\end{tabular}

W: Vina accession; X: Martap accession; Y: Nyambaka accession; Z: Bélel accession ;PH : plants height ; LA : limb area ; PL : petiole lenght; SL: seeds lenght; ST : SWi : Seeds width, Seeds thickness; SWe : seeds weight. Values of a line followed by the same letter are no significantly different. 
Table 3: Dry biomass, carbon stock and carbon credit of castor bean plants.

\begin{tabular}{lcccc}
\hline Parameters & & $\begin{array}{c}\text { Dry biomass } \\
(\mathbf{k g} / \text { plant })\end{array}$ & $\begin{array}{c}\text { Carbon stock } \\
(\mathbf{t} / \mathbf{h a})\end{array}$ & $\begin{array}{c}\text { Carbon credit } \\
(\text { FCFA/ha })\end{array}$ \\
\hline \multirow{3}{*}{ Accessions of } & Vina & $0.66 \pm 0.16^{\mathrm{a}}$ & $1.10 \pm 0.18^{\mathrm{a}}$ & $6200.44 \pm 1069.11^{\mathrm{a}}$ \\
castor bean & Nyambaka & $1.90 \pm 0.76^{\mathrm{b}}$ & $3.18 \pm 0.87^{\mathrm{b}}$ & $17945.62 \pm 5167.40^{\mathrm{b}}$ \\
& Bélel & $1.09 \pm 0.22^{\mathrm{c}}$ & $1.83 \pm 0.30^{\mathrm{c}}$ & $10350.14 \pm 1781.86^{\mathrm{c}}$ \\
& & & $3.26 \pm 0.47^{\mathrm{b}}$ & $18406.99 \pm 2494.60^{\mathrm{b}}$ \\
\hline
\end{tabular}

Values of a column followed by the same letter are no significantly different

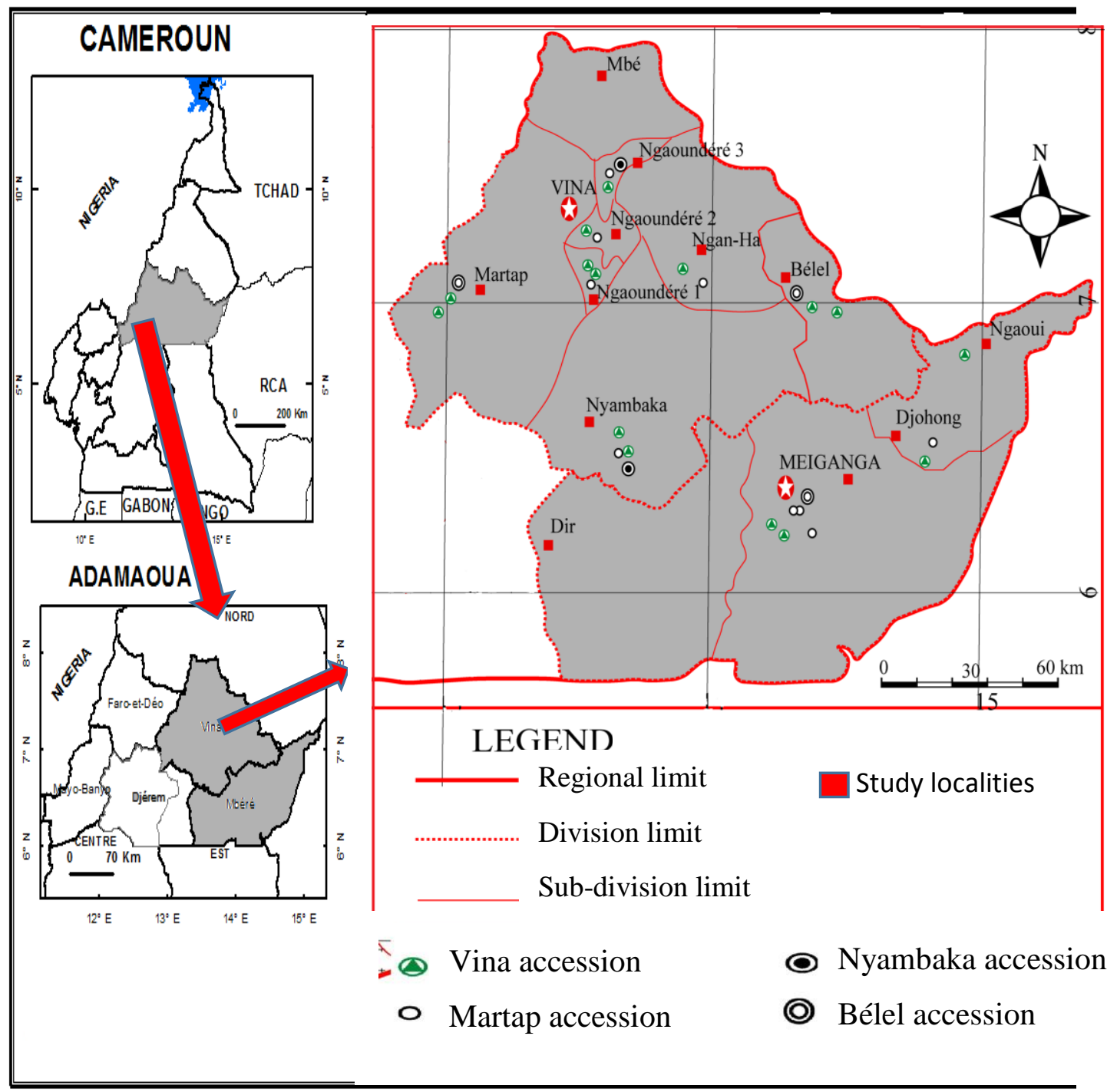

Figure 2 : Position of castor bean accessions on the map of Vina and Mbéré Division of Adamawa Cameroon region. 


\section{DISCUSSION}

The poor knowledge of castor bean by people from the Adamawa region could be explained by the fact this plant is not usually cultivated in the sub-Saharan Africa. Castor bean grows wild in Cameroon (Tchuenteu et al., 2013, Tchuenteu, 2014). It was reported in this study that the rate of use of different parts of castor bean plants varied depending to organ. This could be justified the fact that different organs of our local castor accessions would have different chemical properties. Indeed, N'guessan et al. (2009) in a previous study on Ivorian medicinal plants used in Krobou (Agboville, Côte d'Ivoire) revealed that plants concentrations in sterols, polyterpenes, polyphenols, flavonoids and alkaloids varied depending to the vegetative organ, which gives them various therapeutic properties. In this study, castor bean roots were the most used vegetative organ. In this respect, castor bean roots would be richer on secondary metabolites than leaves and stems. However, a phytochemical screening of various organs of ours local castor bean accessions remains to be studied.

Data obtained in this study on castor bean uses corroborate in part data found in the literature: In fact, Weiss (2000) showed that oil from castor bean is a source of purgative, laxative and anesthetic products. Besides, Mana (2000) revealed that stems of castor bean are used in the manufacture of rock salt; Maroyi (2007) reported that young fruits of this plant are eaten in Bengal (India) and mature leaves are dried and eaten as a vegetable in Korea. It was noted in this study that castor bean is not used in our study area on ornamental, agricultural, pastoral, veterinary, artisanal and industrial levels as several authors have pointed out. Indeed, Pina et al. (2005) revealed that India, China, Brazil and Madagascar industrially grow castor bean. Multiple uses of castor bean observed in this study suggest that the extension of castor bean crop production in Cameroon would contribute to rational exploitation of our local flora, diversifying of raw materials sources and avoiding to exert increased pressure on species of agricultural interest. This will prevent on genetic erosion and environment degrading.

The vegetative organs of castor bean accessions inventoried in this study have presented different colors. This is in accordance with Maroyi (2007) who reported that castor bean can have a beige, brown, green or purple bark.

It was observed in this study that plants height of our local castor bean accessions ranged from $148.63 \pm 19.05$ to $302.96 \pm 44.36$ $\mathrm{cm}$. These results are in line with previous studies. Indeed, several authors (Mana, 2008; Maroyi, 2007; Tchuenteu et al., 2013) revealed that plants height of castor bean varies from 1 to $8 \mathrm{~m}$ depending to genotype and experimental area. Knowing the height of a plant is an important parameter on harvest process. Indeed, fruits harvest of tall plants is hard than those from shorter plants. In this respect, our research group indicated previously that the harvest of castor bean fruits is easier when plants height is less than $2 \mathrm{~m}$. In the current study, plants height of Martap, Nyambaka and Bélel accessions are greater than $2 \mathrm{~m}$ while plants height of Vina accession is less than $1 \mathrm{~m}$, thus suggesting that fruits harvesting of Vina accession would be easier and conversely for Martap, Nyambaka and Bélel accessions.

To the best of our knowledge it was for the first time that leaf blade area of castor bean was evaluated. Foliar production is a recyclable biomass. Indeed, leaves can be degraded under microorganisms actions and release mineral elements necessary to improve soil fertility. Leaf production and plant height are among the main factors to determining seeds yields (Reedy and Matcha, 2010; Tchuenteu, 2014). In this respect, any factor that affects these parameters will also affect plants production. Ours previous studies showed a significant correlation $(p<0.05)$ between plant height and leaf production; between foliar production and seeds yield (Tchuenteu, 2014). Indeed, leaves are the 
organs in charge of photosynthesis. Thus a leaf area increasing of castor bean plants would suggest an increasing of photosynthetic activity, and therefore a seeds yield increasing. In this study, limb area varied depending on castor bean accession: limb area of Bélel accession was found 1.21; 5.51 and 1.6 fold higher than that of Vina, Martap and Nyambaka accessions respectively. The greatest foliar production observed on Bélel accession suggests that this local accession of castor bean would provide the highest seeds yield. However, the potential of adaptability and seeds yield of the four castor accessions identified in the present work remains to be investigated..

Seeds physical characteristics of the local castor bean accessions were different from those found by Perdomo et al. (2013) on 07 local Mexican castor bean accessions. According to these authors reported that that the weight of Mexican castor bean seeds ranged from 0.13 to $0.40 \mathrm{~g}$, seeds length from 1 to $1.5 \mathrm{~cm}$, seeds width from 0.61 to $0.97 \mathrm{~cm}$ and the thickness ranged from 0.46 to 0.71 $\mathrm{cm}$. An interest to study the physical characteristics of seeds lies in that geometric properties of castor seeds provide useful data for engineers in the design of seed-harvesting machines as well as for extracting seeds oils (Tchuenteu, 2014). Seeds weight from the Nyambaka accession was respectively 2.00 , 1.85 and 1.6 fold higher than those of Vina, Martap and Bélel accessions. In this work, physical characteristics of vegetative organs and seeds vary depending on castor bean accessions thus suggesting that it would present different genotypic constitutions, however molecular characterizations of castor bean accessions identified in this work remains to be studied.

Several authors (Pina et al., 2005; Tchuenteu et al., 2013) revealed that castor bean is grown for its seeds rich in oil. Also, castor bean crop would produce a significant vegetative biomass amount. In this respect, this plant would have a strong ability to sequester atmospheric $\mathrm{CO}_{2}$, which is one of the greenhouse gases responsible for global warming. It would therefore be interesting to evaluate the biomass as well as carbon sequestration of 04 local castor bean accessions obtained in this work. Ibrahima and Habib (2008) reported that there is a positive correlation between plants biomass and amount of $\mathrm{CO}_{2}$ sequestered, which justifies the high carbon stock and carbon credit observed on Bélel accession. The high values of plants dry biomass, carbon stock and carbon credit provided by Bélel accession compared to castor Vina, Martap and Nyambaka accessions suggest that this local accession of castor bean could contribute effectively to fight against climate change and desert advancement in the Far North Cameroon. However, the adaptability potential and seeds yield of these local castor accessions remain to deeply investigate.

The geographical distribution of our local castor bean accessions varied depending on localities from the study area, thus indicative that Sub-divisions of the both Divisions, Vina and Mbéré would have different climatic conditions (microclimates) as well as edaphic factors (soils physicochemical properties and soils biological composition). Indeed, plants growth varies according to genotype and experimental area.

\section{Conclusion}

In Vina and Mbéré Divisions of Adamawa Cameroon region, castor bean is used to treat several diseases; seeds oil is consumed and plants present margicoreligious powers. 04 local castor bean accessions (Vina, Martap, Nyambaka and Bélel) were identified. Overall, there is a significant difference between four local castor bean accessions identified on physical characteristics of vegetative organs and seeds. Plants of Bélel accession was the tallest while the smallest plants height were found in Vina accession. Vina accession is the most widespread, followed by Martap accession while the Nyambaka and Bélel accessions are 
the least widespread in our study area. This information will constitute basic data in the implantation program of castor bean as alternative crop for the Cameroonian agriculture. Our future research will focus on evaluating oils physicochemical properties from castor bean accessions identified in order to determine their industrial potential.

\section{COMPETING INTERESTS}

The authors declare that there is no competing interest regarding the publication of this manuscript.

\section{AUTHORS' CONTRIBUTIONS}

CM initiated the study, supervised the work and reread the manuscript. LTT has processed the data and wrote the manuscript. AM carried out the studies (ethnobotanical surveys, determination of the physical characteristics of castor bean accessions, evaluation of carbon stock and carbon credits as well as geolocation of castor bean accessions).

\section{ACKNOWLEDGMENTS}

The authors thank the people in the study area for the hospitality and endogenous sharing of knowledge. They also thank the anonymous readers for their scientific contribution which permited to improve this manuscript.

\section{REFERENCES}

Deffo V, Ottou JF, Ombionyo M, Achundoh LE, Djoumessi M. 2009. Facteurs socioéconomiques affectant l'utilisation dessous-produits agro-industries pour l'embouche bovine à contre saison dans l'Adamawa, Cameroun. Biotechnol. Agron. Soc. Environ., 13(3): 357-365.

Deffo V, Tendonkeng PE, Tchotsoua M, Lieugomg M, Arene CJ, Ethelbert C, Nwagbo EC. 2010. Determination of the best forage production period for cattle farming in the Adamawa Region of Cameroon. Int. J. Biol. Chem. Sci., 4(1): 130-144.
Diallo B, Samba SAN, Sane D, Diop T. 2013. Effet du chlorure de sodium sur la germination de graines de Ricinus communis L. Int. J. Biol. Chem. Sci., 7(4): 1534-1544.

Ezzeddine S, José JMG, Naziha G, Kaouther by, Nizar T, Emilio C. 2017. Studied the genetic variation and seed yield in Tunisian castor bean and revealed that seeds yield varied between populations. Bot. Sci., 95(2): 271-281. DOI: 10.17129/botsci.850

Ibrahima A, Habib F. 2008. Estimation du stock de carbone dans les faciès arborées et arbustives des savanes soudanoguinéennes de Ngaoundéré, Cameroun. In Cameroon J. Expe. Bio., 4(1): 1-11. DOI: http://dx.doi.org/10.4314/cajeb.v4i1.379 70

Lauri PE. 1988. Le mouvement morphogénétique, approche morphométrique et restitution graphique: l'exemple de quelques plantes tropicales. Biologie végétale. Université Montpellier II-Sciences et Techniques du Languedoc. $567 \mathrm{p}$.

Mana J. 2008. Rapport annuel, Fiche technique de culture de Ricinus communis, Sodecoton, DPA/ESA, Cameroun, $7 \mathrm{p}$.

N'guessan K, Kadja B, Zirihi G, Traoré D, Aké-Assi L. 2009. Screening phytochimique de quelques plantes médicinales ivoiriennes utilisées en pays Krobou (Agboville, Côte-d'Ivoire). Sciences \& Nature, 6(1): 1-15.

Mapongmetsem P. 2000. Jardins de case et domestication dans les trophiques: cas des savanes humides du Cameroun (Adamaoua). Com. ICRAF. Agroprolis international, 12p.

Maroyi A. 2007. Ricinus communis L. In : Van der vossen, H.A.M. and Mkmilo, G.S, PROTA 14: Vegetable oil/oléagineux, Wageningen, Pays bas, pp. 12-18. 
191.

DOI:

Ogunniyi DS. 2006. Castor Oil: A vital industrial raw material. Bioresour. Technol., 97: 1086-1091. DOI: https://doi.org/10.1016/j.biortech.2005.0 3.028

Perdomo FA, Acosta OAA, Herrera G, Vasco LJF, Mosquera AJD, Rodriguez GME. 2013. Physicochemical characterization of seven Mexican Ricinus communis L. seeds and oil contents. BIOMASS BIOENERG, 48: 17-24. DOI: 10.1016/j.biombioe.2012.10.020

Pina M, Severino LS, Beltrão NEM, Villeneuve P, Lago R. 2005. De nouvelles voies de valorisation pour redynamiser la filière ricin au brésil. Cah. Agri., 14(1): 169-171.

Reedy KR, Matcha SK. 2010. Quantifying nitrogen effects on castor (Ricinus communis L.) development, growth and pathogensis. Ind Crops Prod, 31:185- 10.1016/j.indcrop.2009.10.004.

Scholz V, Da Silva JN. 2008. Prospects and risks of the use of castor oil as a fuel. Biomass and Bioenergy, 32: 95-100. DOI: 10.1016/j.biombioe.2007.08.004

Tchuenteu TL, Megueni C, Tchobsala, Njintang YN. A Study of the variability for grain and oil yield and oil related traits of castor bean accession in two savannah agroecological zones of Cameroon. Int. J. Biosci. DOI: htt://dx.doi.org/10.12692/ijb/3.8.251-263

Tchuenteu TL. 2014. Caractérisation agronomique de quelques accessions locales de ricin (Ricinus communis L.) cultivées en champ dans le Grand Nord Cameroun et évaluation des propriétés physicochimiques des graines. Thèse de Doctorat. Université de Ngaoundéré. 135 p.

Weiss EA. 2000. Castor. In Oilseed Crops $\left(2^{\text {nd }}\right.$ Edition). Blackwell Scientific Ltd: Oxford; 13-52. 